\title{
Getting the Measure of the Restless City
}

\author{
Des Fitzgerald
}

\begin{abstract}
Questions of mental health and urban life have long been central to Des Fitzgerald's research, and his work with Hubbub has led him to further explore some of the literatures and histories that undergird that relationship, and to think more expansively about the sociology of this emergent space. Critically, engagement with Hubbub has enabled contact with a range of creative practitioners (technoscientific and artistic) interested in very similar kinds of questions. This chapter outlines the development of Des's consideration of the empirics of urban ill-health.
\end{abstract}

Keywords Bodies · Environmental exposure - Interdisciplinary · Mental health . Urban

Why is it that the experience of city living is, for so many people, an experience of unease, if not illness? Why is it that a place that is for many (for me, most of the time) profoundly enlivening in its restlessness and its hurry, can also become, for others, an entirely overwhelming space of noise, disquiet and clamour? What is it about the urban form of life, fundamentally,

D. Fitzgerald $(\bowtie)$

Cardiff University, Cardiff, Wales, United Kingdom

e-mail: FitzgeraldP@cardiff.ac.uk

(C) The Author(s) 2016

F. Callard et al. (eds.), The Restless Compendium,

DOI 10.1007/978-3-319-45264-7_12 
that it associates - and has associated for some time - so strongly with the experience of mental ill health? ${ }^{1}$

Of course there is nothing original (to me) in such questions: as my collaborators and I have elaborated elsewhere, questions like these have concerned scholars of all stripes (as well as other writers and investigators) for more than 100 years. ${ }^{2}$ They continue to capture scholarly and popular attention today: as I was writing this chapter, Scientific American published an in-depth analysis of two new studies on the association between city living and schizophrenia, ${ }^{3}$ Vice carried a story on how placing trees and parks in urban neighbourhoods can have a marked effect on mental health, ${ }^{4}$ and The Guardian suggested that Cardiff (my own city) was notable for having an especially high rate of panic attack. ${ }^{5}$ Such accounts, and the studies they report on, are typical of the wider problem space of urban life and mental health; they draw on a long heritage of attempts to parse the psychogenic effects of the restless city vis-à-vis the calming effects of the bucolic countryside.

I take such questions of public health very seriously, and my attempts to understand this space come through a commitment to contribute to them, however marginally. That contribution is rooted in two wider concerns: (1) a theoretical attention to how bodies and societies, in some sense get in to, or intersect, one another - especially as such intersections take place in illness-inducing, restless spaces of noise and tumult; (2) an empirical concern with how we might come to know, to trace or to measure such intersections.

How, then, do bodies come to matter in urban space today? There are many ways to approach a question like this: one way, for example, would be to focus on what Josh Berson, in this volume, ${ }^{i}$ calls 'social rhythms of rest' - and to assemble the conceptual and material tools for getting some purchase on the bodily states that emerge and disappear within specific urban rhythms. What becomes apparent, in the midst of such an endeavour, is that the question of bodies in cities is not a question of how one impacts, or has an effect on, the other: living-in-the-city is rather about being caught within a very specific set of material-semiotic relations relations between, inter alia, people, bodies, brains, psyches, neighbourhoods, bureaucracies, buildings, noises and so on. To think about mental health in the restless city is to think about what happens when those relations get bent out of shape - when what comes to matter is not only

\footnotetext{
${ }^{i}$ See Chap. 11.
} 
the conviviality and multiplicity of the metropolis, but also alienation and anxiety, stress and sickness. I mean 'comes to matter' here in the sense that the feminist theorist Karen Barad uses this phrase: ${ }^{6}$ I use it in the sense of how something new (a sensation, an illness) materializes; but also in the sense of how this new thing comes to make a difference (biological, political) in the life of a citizen or of a community.

That question of making a difference also reminds us that temporality and novelty are at stake here. We have known, for some time, about the myriad ways that the social and environmental exposures of urban life bear down upon the city dweller. But we still know relatively little about how the digital and biological transformations of the present - which coalesce in the city, though they are not unique to it - might yet torque these exposures, as well as our responses to them. Here, again, the empirical work of Berson and his collaborators can offer some routes in: their entangling of bodily measures and self-reported ambient environmental data, for example, produces new forms of sensory intimacy with a body moving around a city. ${ }^{\text {ii }}$ In attending to these transformations, it is also important to pay attention to other temporally complex, non-digital inhabitants (and producers) of the restless city. I think here especially of animal, arboreal and microbial life - of foxes, forests, bacteria - as these continue to make their presence felt, within the set of material relations through which urban life takes form today. ${ }^{7}$ How this very varied patchwork of restless objects and inhabitants can be brought into some kind of synthetic understanding remains, I think, an open question.

And that question produces an ancillary problem: if we are going to learn to account for the complex ways in which bodies and cities come to inhabit one another, then it may be that what matters here is not so much theory, but measurement. How are we to bring the relationship between mobile bodies and restless cities into some kind of empirical understanding - and to do so with a view to intervening in questions of mental health, at both individual and environmental scales? A great deal of empirical work is underway: we already have, on the one hand, high-quality epidemiological attention to how the forms and stresses of urban life might produce particular symptoms and syndromes. ${ }^{8}$ And we have, on the other hand, a potent and growing ethnographic corpus on the intersections of illness, atmosphere and place, especially as these take shape within urban and peri-urban spaces. ${ }^{9}$ But what we lack, in the most basic sense, is a

\footnotetext{
ii See also Chap. 18.
} 
method for working across these very different sets of empirical procedures. What we do not yet have is some way of accounting for the bodyin-the-city that is able to attend to the two poles of that conjunction, at more or less the same time, with the same level of acuity, and the same degree of nuance, within an understanding that organisms and their environments are simultaneously (if temporarily) their own thing and in relation to one another at the same time.

What kinds of experiments can we imagine for opening up this space? How might we thread an ethnographic attention to place through an epidemiological concern with the specificity of diagnosis, and vice versa, precisely so as to mirror the cat's cradle of relations, intersections and wrappings that take place between and across cities and bodies? ${ }^{10}$ How might we leverage precisely the same computational and digital transformations that are, as we speak, remaking a range of urban landscapes, in order to make those landscapes visible, measurable, even modifiable? These are the questions we'll need to answer, if we are truly going to get the measure of the restless city.

\section{Notes}

1. Dana March et al., 'Psychosis and Place', Epidemiologic Reviews 30, no. 1 (2008): 84-100.

2. Des Fitzgerald, Nikolas Rose, and Ilina Singh, 'Living Well in the Neuropolis', The Sociological Review 64, no. 1 (2016): 221-37.

3. Diana Kwon, 'Does City Life Pose a Risk to Mental Health?', Scientific American, accessed 26 June 2016, http://www.scientificamerican.com/ article/does-city-life-pose-a-risk-to-mental-health/.

4. Lucy Jones, 'Green Peace: How Nature Actually Benefits Your Mental Health', VICE, 24 May 2016, https://www.vice.com/en_uk/read/ why-is-nature-actually-good-for-your-mental-health.

5. Amy Fleming, 'Which UK City Suffers the Most Panic Attacks?', The Guardian, 24 March 2016, sec. Cities, https://www.theguardian.com/ cities $/ 2016 / \mathrm{mar} / 24 /$ panic-attack-poll-swansea-most-panic-stricken-city.

6. Karen Barad, Meeting the Universe Halfway: Quantum Physics and the Entanglement of Matter and Meaning (Durham, N.C.: Duke University Press, 2007).

7. Robert Lee Hotz, 'Big Data and Bacteria: Mapping the New York Subway's DNA', Wall Street Journal, 5 February 2015, sec. US, http:// www.wsj.com/articles/big-data-and-bacteria-mapping-the-new-yorksubways-dna-1423159629; Jesse Ausubel, 'The Return of Nature: How Technology Liberates the Environment', The Breakthrough, Spring 2015, 
http://thebreakthrough.org/index.php/journal/issue-5/the-return-ofnaturehttp://thebreakthrough.org/index.php/journal/issue-5/ the-return-of-nature.

8. Florian Lederbogen, Leila Haddad, and Andreas Meyer-Lindenberg, 'Urban Social Stress-Risk Factor for Mental Disorders. The Case of Schizophrenia', Environmental Pollution 183 (December 2013): 2-6.

9. Michelle Murphy, 'The "Elsewhere within Here" and Environmental Illness; Or, How to Build Yourself a Body in a Safe Space', Configurations 8, no. 1 (2000): 87-120.

10. Donna Haraway, ModestWitness@Second_Millennium. FemaleMan_Meets_ OncoMouse: Feminism and Technoscience (New York, N.Y.: Routledge, 1997).

\section{FURTHER READING}

Adli, Madza. 'Urban Stress and Mental Health'. LSECities, November 2011. https://lsecities.net/media/objects/articles/urban-stress-and-mentalhealth/en-gb/.

Benedictus, Leo. 'Sick Cities: Why Urban Living Can Be Bad for Your Mental Health'. The Guardian, 25 February 2014, sec. Cities. https://www.theguardian. $\mathrm{com} /$ cities $/ 2014 / \mathrm{feb} / 25 /$ city-stress-mental-health-rural-kind.

Choy, Timothy K. Ecologies of Comparison: An Ethnography of Endangerment in Hong Kong. Durham, N.C.: Duke University Press, 2011.

Lederbogen, Florian, P. Kirsch, L. Haddad, F. Streit, H. Tost, P. Schuch, S. Wüst, et al. 'City Living and Urban Upbringing Affect Neural Social Stress Processing in Humans'. Nature 474, no. 7352 (23 June 2011): 498-501.

Fitzgerald, Des, Nikolas Rose, and Ilina Singh 'Revitalizing Sociology: Urban Life and Mental Illness between History and the Present'. British Journal of Sociology 67, no. 1 (2016): 138-60.

Des Fitzgerald is a sociologist of science and medicine at Cardiff University, with a particular interest in the history and present of the neurosciences. $\mathrm{He}$ is coauthor of Rethinking Interdisciplinarity across the Social Sciences and Neurosciences (Palgrave Macmillan, 2015).

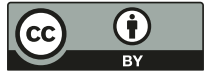

This chapter is distributed under the terms of the Creative Commons Attribution 4.0 International License (http://creativecommons.org/ licenses/by/4.0/), which permits use, duplication, adaptation, distribution and reproduction in any medium or format, as long as you give appropriate credit to the original author(s) and the source, a link is provided to the Creative Commons license and any changes made are indicated. 
104 D. FITZGERALD

The images or other third party material in this chapter are included in the work's Creative Commons license, unless indicated otherwise in the credit line; if such material is not included in the work's Creative Commons license and the respective action is not permitted by statutory regulation, users will need to obtain permission from the license holder to duplicate, adapt or reproduce the material. 